\title{
Biodiversity of Bangladesh
}

\author{
Sharif A. Mukul ${ }^{1,2,3, *}$, Shekhar R. Biswas ${ }^{4}$ and A. Z. M. Manzoor Rashid ${ }^{5}$ \\ ${ }^{1}$ Department of Environmental Management, School of Environmental Science and \\ Management, Independent University, Dhaka 1229, Bangladesh \\ ${ }^{2}$ Tropical Forests and People Research Centre, University of the Sunshine Coast, \\ Maroochydore DC, Qld 4558, Australia \\ ${ }^{3}$ School of Geography, Planning and Environmental Management, The University of \\ Queensland, Brisbane, Qld 4072, Australia \\ ${ }^{4}$ Department of Biology, Lakehead University, Thunder Bay, ON P7B 5E1, Canada; \\ s.mukul@uq.edu.au \\ ${ }^{5}$ Department of Forestry and Environmental Science, School of Agriculture and Mineral \\ Sciences, Shahjalal University of Science and Technology, Sylhet 3114, Bangladesh; \\ pollen_forest@yahoo.com \\ *Correspondence: sharif_a_mukul@yahoo.com or smukul@iub.edu.bd
}

\begin{abstract}
Biodiversity has become an issue of global anxiety over the past decades due to its rapid decline worldwide. Bangladesh as one of the most densely populated countries in the world is no more exception. The country, although, was once very rich in biodiversity, during the last few decades as a consequence of the rapid reduction in forest area, urbanisation, habitat modification, unsustainable natural resources use and collection and overall climate change it has decreased alarmingly. Of late, the government, as a signatory of various regional and international conservation treaties, has taken various initiatives to improve country's dwindling biodiversity. This paper reviews the present situation of biodiversity in Bangladesh, management trends and major causes of biodiversity loss. A separate statutory body is fundamental to ensure conservation, sustainable use and equitable sharing of benefits arisen from biodiversity in the country.
\end{abstract}

Keywords: biodiversity loss; conservation; deforestation; Bangladesh

\section{INTRODUCTION}

Bangladesh is situated in the world largest deltaic plain - the Ganges- Brahmaputra delta, in the north-eastern part of South Asia between $20^{\circ} 34^{\prime}$ and $26^{0} 38^{\prime}$ North latitude and $88^{\circ} 01^{\prime}$ and $92^{0} 41^{\prime}$ East longitude. The country mostly consists of flood plains with some hilly areas, with a sub-tropical monsoon climate (Islam, 2003). In the country, about $80 \%$ of the land is lowlying and/or flooded at least during the monsoon, makes the country the single largest floodbasin in South Asia. The majority of country's land is formed by river alluvium from the 
Ganges and the Brahmaputra and their tributaries (Sohel et al., 2015). Geographically, the country falls near the Indo-Burma region - one of the global biodiversity hot-spot and believed to have more than 7,000 endemic plant species (Mittermeier et al., 1998).

Bangladesh, due to its unique geophysical location and a suitable climatic condition is exceptionally endowed with a rich variety of biodiversity (Nishat et al., 2002). Nevertheless, in last years, like most other regions of the world, Bangladesh also went through a critical period unsuitable for country's biodiversity and ecosystem. The government so far along with various international conservation agencies has also been trying to improve and manage this overwhelming situation. This chapter aims to provide an insight of the biodiversity of Bangladesh, from ecosystem to species level, genetic diversity, and major threats to the biodiversity in the country with key initiatives so far taken for biodiversity conservation.

\section{MAJOR ECOSYSTEMS OF BANGLADESH}

Ecologically Bangladesh supports a diverse set of ecosystems. The country, has the world's largest continuous mangrove forest - The Sundarbans on its southwestern part- habitat of the world's largest surviving population of the Royal Bengal tiger (Panthera tigris); in its eastern part it has a large tract of evergreen to semi-evergreen hill forests, once very rich in biodiversity but mostly degraded now; besides in the north-eastern part there are many wetlands, locally called haors that harbor a huge number of aquatic plants, migratory birds and freshwater fish species (Khan et al., 2007).

The forests of Bangladesh cover three major vegetation type occurring in three distinctly different ecosystems, i.e. hill forests (evergreen to semi-evergreen); plain land Sal (Shorea robusta) forests and mangrove forests. Although, once very rich in biodiversity during the last few decades all forest and ecosystems of the country have been heavily degraded (Mukul et al., 2008). There have some contradictions on the actual forest coverage of the country. Although the official forest coverage is 2.53 million ha (see Table 1) representing nearly $17.5 \%$ of the country's total land area, only 1.52 million ha of them are under the jurisdiction of the Forest Department (Khan et al., 2007; FAO, 2006). In addition to that, most of the forests of the country are geographically located only in few districts and are poorly stocked (Figure 1). 


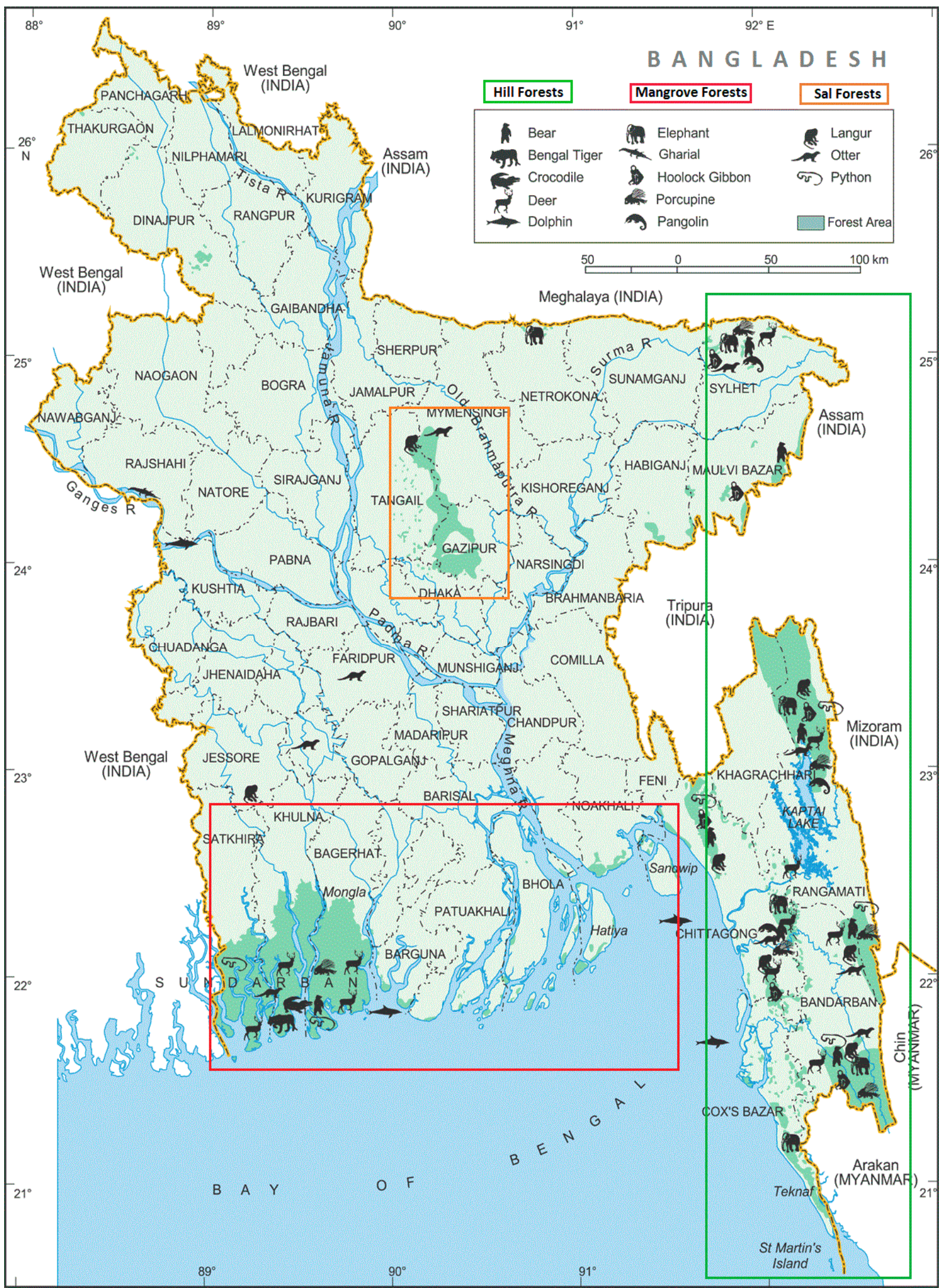

FIGURE 1. Major forest types and distribution of wildlife in Bangladesh. 
TABLE 1. Major forest types and areas in Bangladesh

\begin{tabular}{|c|c|c|c|}
\hline Forest type & Location & $\begin{array}{l}\text { Area } \\
\text { (million ha) }\end{array}$ & Remarks \\
\hline \multicolumn{4}{|l|}{ Hill forests } \\
\hline $\begin{array}{l}\text { Managed reserved forest } \\
\text { (evergreen to semi-evergreen) }\end{array}$ & $\begin{array}{l}\text { Eastern part of the country } \\
\text { (Chittagong, Chittagong Hill Tracts } \\
\text { and Sylhet) }\end{array}$ & 0.67 & $\begin{array}{l}\text { Highly degraded and managed by the Forest } \\
\text { Department. }\end{array}$ \\
\hline Unclassed State Forest (USF) & Chittagong Hill Tracts & 0.73 & $\begin{array}{l}\text { Under the control of district administration and } \\
\text { denuded mainly due to faulty management and } \\
\text { shifting cultivation. Mainly scrub forest. }\end{array}$ \\
\hline \multicolumn{4}{|l|}{ Plain land Sal forests } \\
\hline Tropical moist deciduous forest & $\begin{array}{l}\text { Central and north-western region } \\
\text { (Dhaka, Mymensingh, Tangail etc.) }\end{array}$ & 0.12 & $\begin{array}{l}\text { Mainly Sal forest but now converting to exotic } \\
\text { short rotation plantations. Managed by the } \\
\text { Forest Department. }\end{array}$ \\
\hline \multicolumn{4}{|l|}{ Mangrove forests } \\
\hline Sundarbans & Southwest (Khulna, Satkhira) & 0.57 & $\begin{array}{l}\text { World's largest continuous mangrove forest and } \\
\text { including } 0.17 \text { million ha of water. }\end{array}$ \\
\hline Coastal plantations & $\begin{array}{l}\text { Along the shoreline of twelve } \\
\text { districts }\end{array}$ & 0.10 & $\begin{array}{l}\text { Mangrove plantations along the shoreline of } 12 \\
\text { districts. Managed by Forest Department. }\end{array}$ \\
\hline Village forests & $\begin{array}{l}\text { Homestead forests all over the } \\
\text { country }\end{array}$ & 0.27 & $\begin{array}{l}\text { Diversified productive system. Fulfill majority } \\
\text { of country's domestic timber, fuelwood and } \\
\text { bamboo requirements. }\end{array}$ \\
\hline $\begin{array}{l}\text { Tea gardens and rubber } \\
\text { plantations }\end{array}$ & Chittagong Hill Tracts and Sylhet & 0.07 & $\begin{array}{l}\text { Plantations of tree and rubber with various short } \\
\text { rotation species as shade tree. }\end{array}$ \\
\hline Total & & 2.53 & $17.49 \%$ of country's landmass \\
\hline
\end{tabular}

Source: Mukul et al. (2014a); Khan et al. (2007) 


\section{PLANT AND WILDLIFE DIVERSITY IN BANGLADESH}

In Bangladesh, some 2,260 species of plant reported alone from the Chittagong Hill Tracts, which falls between two major floristic regions of Asia (MoEF, 1993). Until now, an estimated 5,700 species of angiosperms alone, including 68 woody legumes, 130 fibre yielding plants, 500 medicinal plants, 29 orchids, 3 gymnosperms and 1,700 pteridophytes have been recorded from the country (Firoz et al., 2004).

The country also possesses a rich faunal diversity. Bangladesh is home of about 138 mammal species, more than 566 species of birds (passerine and non-passerine), 167 species of reptiles, 49 species of amphibians (Figure 2; IUCN 2016). In addition to that, at least 253 species of fish (inland freshwater), 305 species of butterflies, 305 species of shrimp/prawn, 2,493 species of insects, 362 species of mollusks, 66 species of corals, 15 species of crabs, 19 species of mites, 164 species of algae, 4 species of echinoderms are believed to be exist in the country (IUCN 2015 \& 2000; Islam et al. 2003).

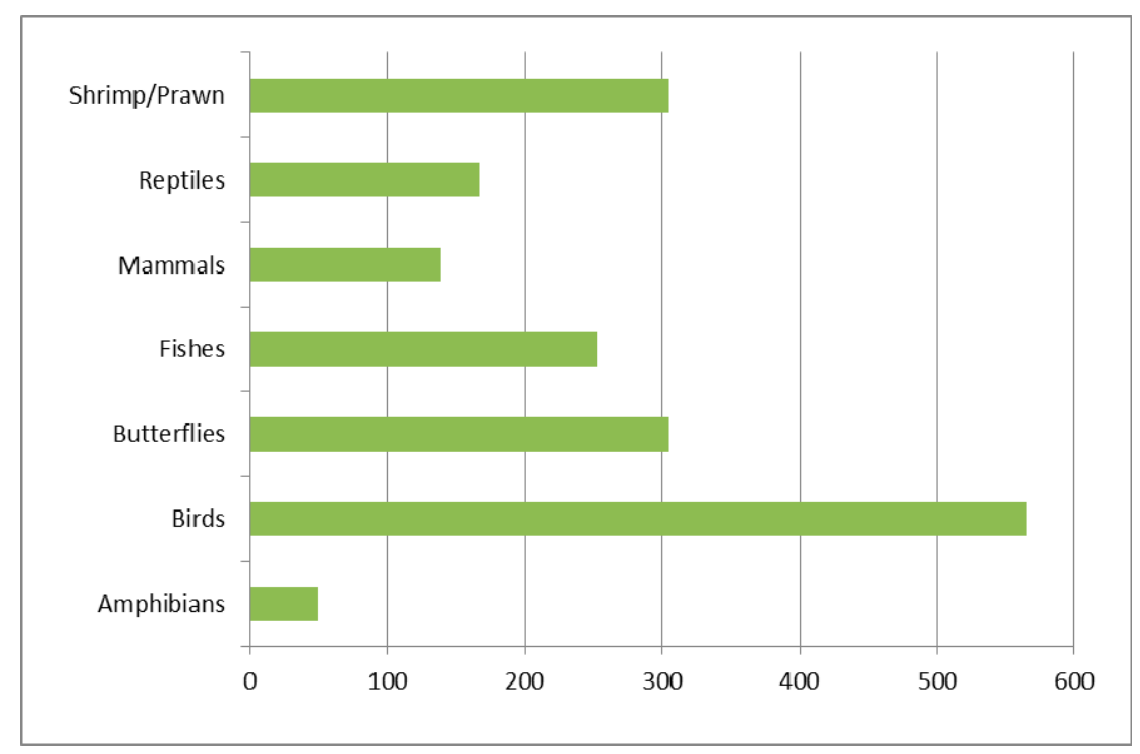

FIGURE 2. Faunal diversity of Bangladesh

\section{GENETIC AND CROP DIVERSITY IN BANGLADESH}

Bangladesh has a very rich in agro-biodiversity and supposed to have more than 8,000 rice varieties along with 3,000 crop varieties. Other than these more than 3000 varieties of pulses, 781 varieties of oilseed, 3516 vegetables (both species and cultivar), 156 spices, 89 fruits, are recorded alone by the Bangladesh Agricultural Research Council (Chowdhury, 2012). There are also more than 5000 varieties (both species and cultivar) of jute, and 475 varieties of tea recorded from the country. Many of these species varieties are however currently under threat due to the massive cultivation of certain high yielding rice and crop varieties and excessive use of agrochemicals in crop fields. 


\section{THREATENED BIODIVERSITY IN BANGLADESH}

A great number of plant and wildlife species have already gone extinct from Bangladesh over the last decades (Rahman, 2004). Table (2) outlined the extinct mammal species in the country. A substantial number of country's remaining plants, mammals, birds and reptiles are currently under tremendous pressure. IUCN (2015) has listed a total of 156 species of mammals, birds, reptiles and amphibians under various degrees of risks in the country (Table 3). A reliable statistic on country's plant diversity is still unavailable, nevertheless, it is anticipated that already $10 \%$ of country's plant species gone extinct. A recent inventory by Bangladesh National Herbarium identified 106 vascular plants with risks of various degrees of threats (Khan et al., 2001).

TABLE 2. Mammalian species extinct from Bangladesh in the past decades

\begin{tabular}{ll}
\hline Common name & Scientific name \\
\hline Great one-horned rhinoceros & Rhinoceros unicornis \\
Javan rhinoceros & Rhinoceros sondiacus \\
Asiatic two-horned rhinoceros & Didermocerus sumatrensis \\
Blue bull /nilgai & Boselaphus tragocamelus \\
Wild buffalo & Bubalus bubalis \\
Gaur & Bos gaurus \\
Banteng & Bos banteng \\
Swamp deer & Cervus duvauceli \\
Marbled cat & Canis lupus \\
Sloth beer & Melursus ursinus \\
\hline
\end{tabular}

Sources: IUCN (2015 \& 2000)

TABLE 3. Present status of inland and resident vertebrates in Bangladesh

\begin{tabular}{|c|c|c|c|c|c|c|}
\hline \multirow{2}{*}{ Group } & \multirow{2}{*}{$\begin{array}{l}\text { Total no. } \\
\text { of species }\end{array}$} & \multirow[b]{2}{*}{ Extinct } & \multicolumn{4}{|l|}{ Threatened } \\
\hline & & & $\begin{array}{l}\text { Critically } \\
\text { endangered }\end{array}$ & Endangered & Vulnerable & Total \\
\hline Amphibians & 49 & 0 & 2 & 3 & 5 & 10 \\
\hline Reptiles & 167 & 1 & 17 & 10 & 11 & 39 \\
\hline Birds & 566 & 19 & 10 & 12 & 17 & 58 \\
\hline Mammals & 138 & 11 & 17 & 12 & 9 & 49 \\
\hline Total & 920 & 31 & 46 & 37 & 42 & 156 \\
\hline
\end{tabular}

Source: IUCN (2015)

\section{BIODIVERSITY CONSERVATION INITIATIVES IN BANGLADESH}

Despite a rapid loss and degradation of wild habitats, biodiversity conservation has received a wider attention in Bangladesh in the present years (Mukul et al., 2017; Mukul, 2007). The government of Bangladesh, as a signatory party to various regional and international conservation related agreement and conventions, are now increasingly committed to 
conserving country's remaining biodiversity. Already the government has ratified five major biodiversity-related conventions (i.e. Convention on Biological Diversity, Convention on International Trade in Endangered Species, Convention on the Conservation of Migratory Species, Ramsar Convention, and World Heritage Convention).

The country has also adopted various in situ and ex situ conservation measures to maintain its rich biological heritage. Declaration of protected areas, ecologically critical areas, World Heritage Site, Ramsar Sites are among the widely used ways for in situ conservation (Mukul et al., 2008). At present, the country has 38 protected areas including 17 national parks and 21 wildlife sanctuaries distributed across the country. Together, the protected areas of Bangladesh cover nearly $17.5 \%$ of the forest area and $1.8 \%$ of country's total land area (Mukul et al., 2017; Mukul et al., 2008). In addition to that, the country has seven eco-park, two safari park and botanical gardens which also contribute significantly to the conservation of country's dwindling biodiversity.

\section{CHALLENGES AND MAJOR THREATS TO BIODIVERSITY IN BANGLADESH}

Biodiversity loss in Bangladesh is attributed to several socio-economic, bio-physical and organizational factors (Mukul et al., 2014b \& 2012a). Following are some key reasons behind the rapid biodiversity loss in the country.

i. High population density, extreme poverty, and unemployment: Bangladesh is one of the world's densely populated countries with an extreme poverty and high unemployment rate. More than $85 \%$ population of the country are living in rural areas and somehow depends on various natural resources which lead to exploitation of plant and animal products for people's livelihood and income (Mukul et al., 2012a). Rural fuel consumption pattern, which is strongly concerned with degradation of natural forest area is another important issue related to biodiversity depletion in the country (Mukul et al., 2014c).

ii. Climate change and sea level rise: Bangladesh is one of the largest victims of climate change and associated sea level rise. The majority of the country will go under water if the water level rises by $50 \mathrm{~cm}$. The country has already experienced severe change in precipitation pattern, temperature etc. The climate change in the country will largely impact the persistence of large living animals and the ecosystems of which they are part (Alamgir et al., 2015).

iii. Habitat loss, degradation and fragmentation: Biodiversity conservation is strongly associated with the intact ecosystems and natural landscape, however, transformation of land use patterns, expansion of agricultural lands, changes in cropping pattern, introduction of high yielding varieties, urbanization, expansion of road networks, embankments, and other manmade factors have caused immense damage to wild habitats in all ecosystem types in the country. Following are some common reason of habitat loss, degradation, and fragmentation: 
o Land use change and agricultural expansions

o Encroachment

o Shifting cultivation

o Urbanization

o Commercial shrimp cultivation in coastal areas

iv. Illegal poaching, logging and fuel wood collection: There is a big international market (largely illegal) of unregulated wild animals and their parts (e.g. teeth, bones, fur, ivory) mainly for their aesthetic and medicinal value (see Mukul et al., 2012b\& 2014b).

Besides, illegal logging, fuelwood collection, unsustainable harvest of non-timber forest products including medicinal plants are also responsible for the depletion of biodiversity in the country (Mukul et al., 2010; Khan et al., 2009).

v. Environmental pollution and degradation: One of the major threats to aquatic biodiversity in Bangladesh is pollution of soil and water. The aquatic ecosystem is the greatest victim and is polluted by toxic agrochemicals (i.e. chemical fertilisers, insecticides) and industrial effluents that cause depletion of aquatic and/or marine biodiversity.

vi. Invasive alien species: A large number of exotic and non-native plant species have been introduced to the country since British colonial period for agriculture, horticulture, forestry, and fisheries (Mukul et al., 2006). Some of the species have become escapes accidentally and having adapted to local conditions proliferated profusely. Some species although have naturalised but many have become invasive over local flora and fauna. Besides, replacing natural plantation with the monoculture of short rotation and fast growing species have threatened the existence of local fauna as they have not adapted to those species (Uddin et al., 2013).

vii. Limitations in legal and policy framework: Lack of adequate institutional or administrative frameworks and suitable policies, weak implementation of existing policies, lack of integration of sectoral activities are other additional challenges to the biodiversity conservation in Bangladesh (Chowdhury et al., 2014; Rashid et al., 2013). Besides, poor coordination and cross-sectoral integration, weak national information system and inadequate knowledge on ecosystem structure and function are the vital reason for biodiversity loss in the country.

viii. Lack of political commitments and willingness: Unfortunately, there are no dealings of biodiversity, forestry or other relevant issues in the political campaign of the parties. In some cases, politically influential and elite persons are found involved in environmental degradation and illegal forest activities (e.g. encroachment).

ix. Lack of public awareness: Lack of biodiversity-related information and knowledge inevitably leads to poor awareness and capacity for biodiversity conservation. Gaps in 
awareness have identified at various levels from policy makers to grass root people that sometimes even leads to misappropriation of existing law. Besides, the lack of appropriate implementation of existing biodiversity laws and regulation are common in the country.

\section{CONCLUDING REMARKS}

Bangladesh is one of the most vulnerable countries due to global climate change and consequential sea level rise. The government should immediately seek for proper adaptation measures to cope with this inevitable event. Besides, focusing only on ecological aspects will not provide a long-term security of biodiversity conservation in the country since people still substantially depend on these resources for their existence. The government should actively involve local community people in natural resource management to secure the future of country's biological diversity. A well-coordinated program on monitoring and management of country's biodiversity is an urgent task. Inadequate institutional capacities and lack of trained manpower are the attributes of biodiversity and conservation issues malfunction in dealing with. Finally, government laws concerning biodiversity issue requires urgent reform considering country's changing socio-political context and the environment.

\section{REFERENCES}

Alamgir M, Mukul SA, Turton S (2015). Modelling spatial distribution of critically endangered Asian elephant and Hoolock gibbon in Bangladesh forest ecosystems under a changing climate. Applied Geography, 60: 10-19.

Chowdhury MKA (2012) Conservation and sustainable use of plant genetic resources in Bangladesh. Dhaka (Bangladesh): Bangladesh Agricultural Research Council (BARC).

Chowdhury MSH, Gudmundsson C, Izumiyama S, Koike M, Nazia N, Rana MP, Mukul SA, Muhammed N, Redowan M (2014) Community attitudes toward forest conservation programs through collaborative protected area management in Bangladesh. Environment, Development and Sustainability, 16: 1235-1252.

FAO (2006). Global Forest Resource Assessment 2005: Progress towards sustainable forest management, FAO Forestry Paper 147. Rome (Italy): Food and Agriculture Organization of the United Nations (FAO).

Firoz R, Mobasher SM, Waliuzzaman M, Alam MK (eds) (2004) Proceedings of the Regional Workshops on National Biodiversity Strategy and Action Plan. Dhaka: IUCN Bangladesh Country Office.

Islam MM, Amin ASMR, Sarker SK (2003) National Report on Alien Invasive Species of Bangladesh. In: Pallewatta N, Reaser JK, Gutierrez AT, ( eds). Invasive Alien Species in South-Southeast Asia: National Reports \& Directory of Resources. Cape Town (South Africa): Global Invasive Species Programme (GISP). pp. 7-24.

Islam SS (2003) State of forest genetic resources conservation and management in Bangladesh, Forest Genetic Resources Working Papers, Working Paper FGR/68E. Rome (Italy): Forest Resources Division, FAO. 
IUCN (2000). Red list of threatened animals of Bangladesh. Dhaka: The World Conservation Union.

IUCN (2015) Red list of Bangladesh - a brief on assessment result 2015. Dhaka: The World Conservation Union.

Khan MASA, Mukul SA, Uddin MS, Kibria MG, Sultana F (2009). The use of medicinal plants in health care practices by Rohingya refugees in a degraded forest and conservation area of Bangladesh. International Journal of Biodiversity Science and Management, 5: 76-82.

Khan MASA, Uddin MB, Uddin MS, Chowdhury MSH, Mukul SA (2007). Distribution and Status of Forests in the Tropic: Bangladesh Perspective. Proc. Pakistan Acad. Sci., 44: 145-153.

Khan MS, Rahman MM, Ali MA (2001) Red Data Book of Vascular Plants of Bangladesh. Dhaka: Bangladesh National Herbarium.

Mittermeier RA, Myers N, Thomsen JB, Da Fonseca GA, Olivieri S (1998) Biodiversity hotspots and major tropical wilderness areas: approaches to setting conservation priorities. Conservation Biology, 12: 516-20.

MoEF (1993) Forestry Master Plan-Main Report, ADB (TA No. 1355-BAN), UNDP/FAO BGD 88/025. Dhaka: Ministry of Environment and Forest (MoEF).

Mukul SA (2007). Biodiversity conservation strategies in Bangladesh: the state of protected areas. Tigerpaper, 34: 28-32

Mukul SA, Biswas SR, Rashid AZMM, Miah MD, Kabir ME, Uddin MB, Alamgir M, Khan NA, Sohel MSI, Chowdhury MSH, Rana MP, Rahman SA, Khan MASA, Hoque MA (2014a) A new estimate of carbon for Bangladesh forest ecosystems with their spatial distribution and REDD+ implications. International Journal of Research on Land-use Sustainability, 1: 33-41.

Mukul SA, Herbohn J, Rashid AZMM, Uddin MB (2014b) Comparing the effectiveness of forest law enforcement and economic incentive to prevent illegal logging in Bangladesh. International Forestry Review, 16: 363-375.

Mukul SA, Tito MR, Munim SA (2014c) Can homegardens help save forests in Bangladesh? Domestic biomass fuel consumption patterns and implications for forest conservation in south-central Bangladesh. International Journal of Research on Land-use Sustainability, 1: 18-25.

Mukul SA, Rashid AZMM, Khan NA (2017) Forest protected area systems and biodiversity conservation in Bangladesh. In: Mukul SA, Rashid AZMM (eds.) Protected Areas: Policies, Management and Future Directions. New York: Nova Science Publishers, Inc., pp. 157-177.

Mukul SA, Rashid AZMM, Quazi SA, Uddin MB, Fox J (2012a). Local peoples' response to co-management in protected areas: A case study from Satchari National Park, Bangladesh. Forests, Trees and Livelihoods, 21: 16-29.

Mukul SA, Rashid AZMM, Uddin MB (2012b) The role of spiritual beliefs in conserving wildlife species in religious shrines of Bangladesh. Biodiversity, 13: 108-114.

Mukul SA, Uddin MB, Rashid AZMM, Fox J (2010) Integrating livelihoods and conservation in protected areas: understanding role and stakeholders' views on the prospects of 
non-timber forest products, A Bangladesh case study. International Journal of Sustainable Development and World Ecology, 17: 180-188.

Mukul SA, Uddin MB, Tito MR (2006) Study on the status and various uses of invasive alien plant species in and around Satchari National Park, Sylhet, Bangladesh. Tigerpaper, 33: 28-32.

Mukul SA, Uddin MB, Uddin MS, Khan MASA, Marzan B (2008) Protected areas of Bangladesh: current status and efficacy for biodiversity conservation. Proc. Pakistan Acad. Sci., 45: 59-68.

Nishat A, Huq SMI, Barua SP, Reza AHMA, Khan ASM (2002) Bio-ecological Zones of Bangladesh. Dhaka: The World Conservation Union.

Rahman MM (2004). Forest resources of Bangladesh with reference to conservation of biodiversity and wildlife in particular for poverty alleviation. In: Sim HC, Appanah S, Youn YC (eds). Forests for Poverty Reduction: opportunities with clean development mechanism, environmental services and biodiversity. Bangkok. (Thailand): FAORegional office for Asia and the Pacific (FAO-RAP); pp. 139-48.

Rashid AZMM, Craig D, Mukul SA, Khan NA (2013) A journey towards shared governance: status and prospects of collaborative management in the protected areas of Bangladesh. Journal of Forestry Research, 24: 599 -605.

Sohel MSI, Mukul SA, Chicharo L (2015) A new ecohydrological approach for ecosystem service provisions and sustainable management of aquatic ecosystems in Bangladesh. Ecohydrology \& Hydrobiology, 15: 1-12.

Uddin MB, Steinbauer MJ, Jentsch A, Mukul SA, Beierkuhnlein C (2013). Do environmental attributes, disturbances, and protection regimes determine the distribution of exotic plant species in Bangladesh forest ecosystem? Forest Ecology and Management, 303: $72-80$. 

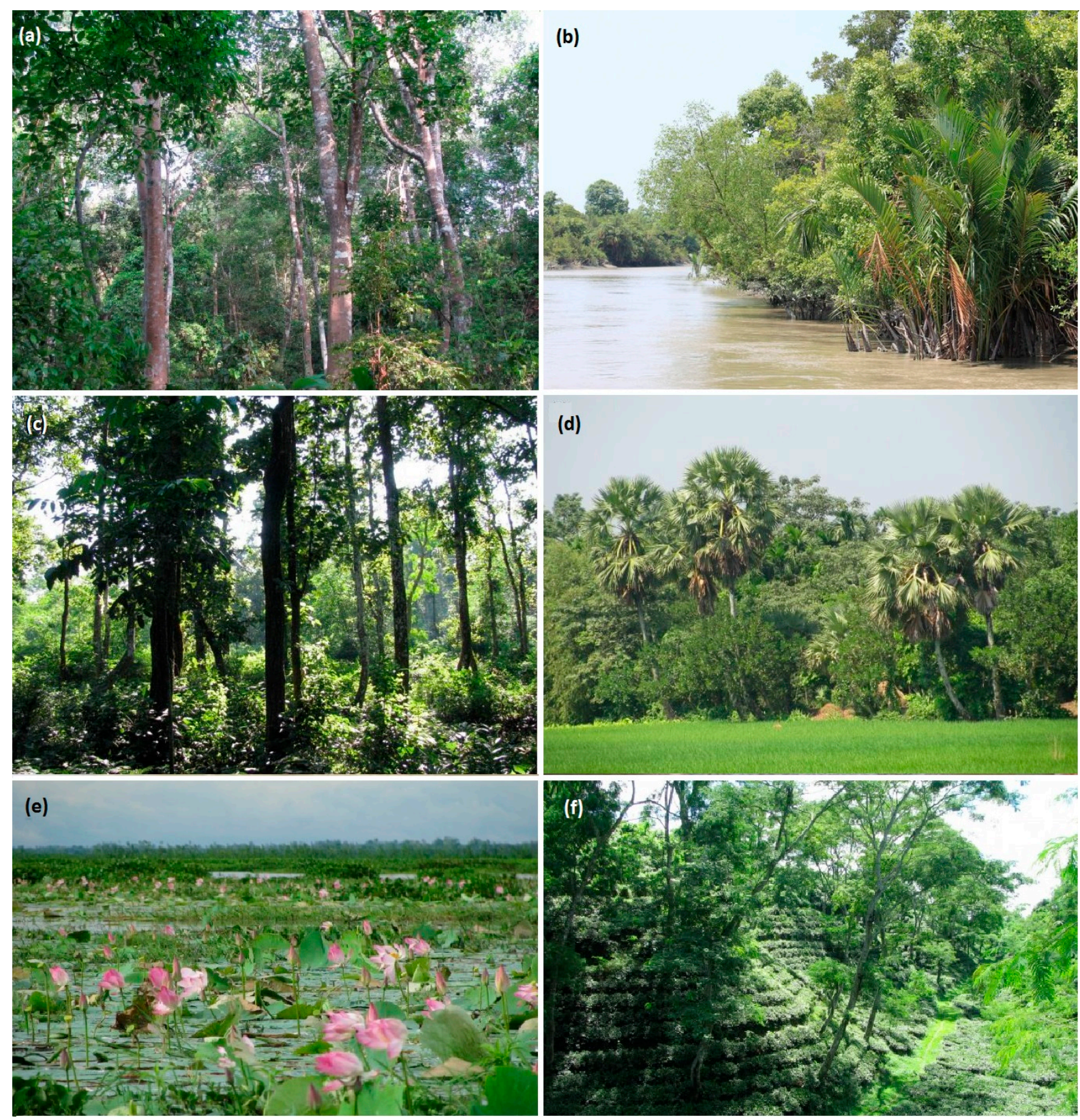

PLATE 1: Ecosystem diversity in Bangladesh: from top left - (a) hill forests dominated by dipterocarp species, (b) mangrove forests of Sundarbans, (c) Sal (Shorea robusta) forests in central Bangladesh, (d) homestead forests managed by the rural landowners, (e) Lotus (Nelumbo nucifera) flower in wetlands, and (f) Tea (Camellia sinensis) gardens in north-east Bangladesh.

(Photo credits: Sharif A. Mukul) 

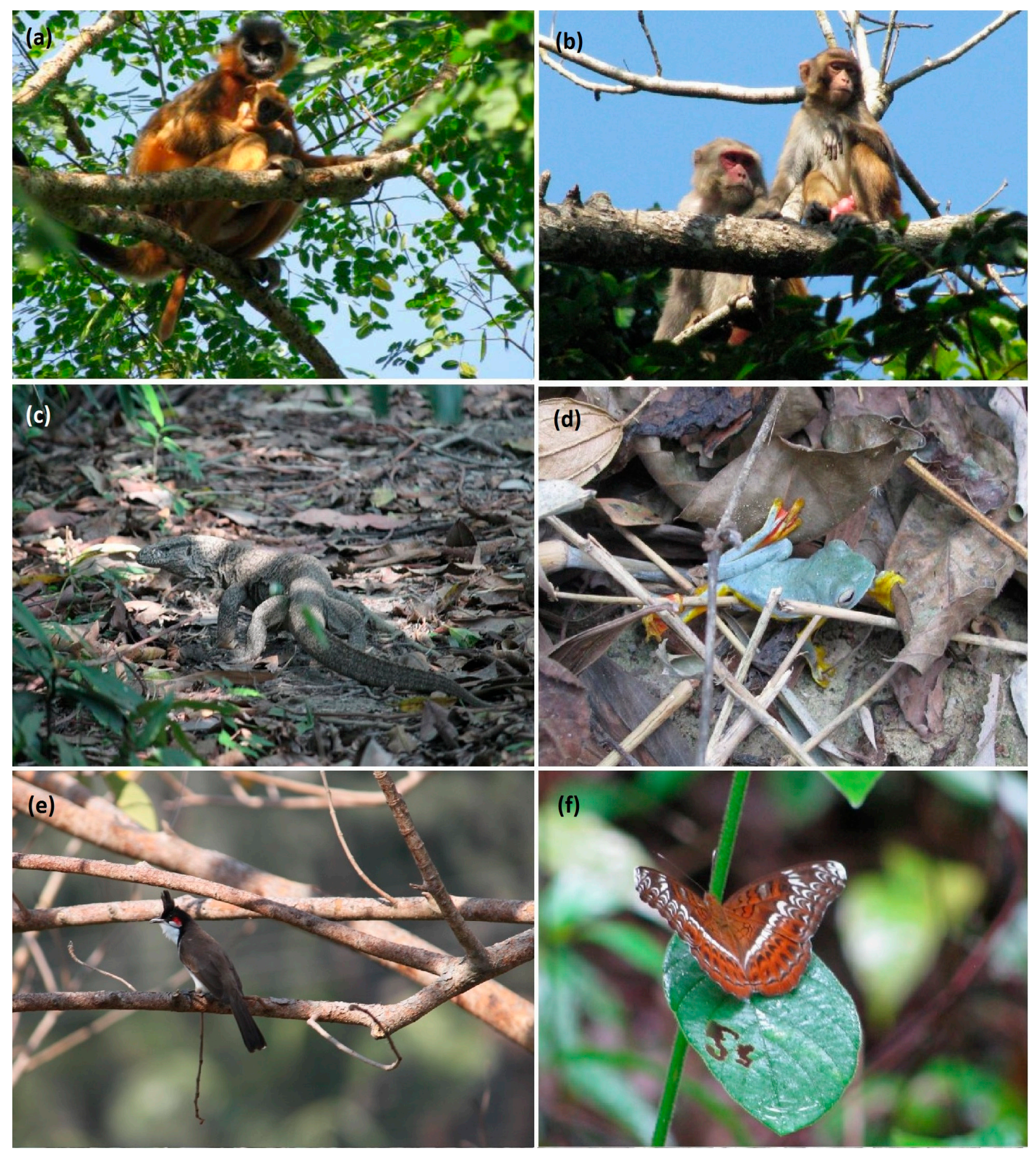

PLATE 2: Wildlife diversity in Bangladesh: from top left - (a) Capped langur (Presbytis pileatus), (b) Rhesus macaque (Macaca mulatta), (c) Bengal monitor (Varanus bengalensis), (d) Twin-spotted tree frog (Rhacophorus bipunctatus), (e) Red-whiskered bulbul (Pycnonotus jocosus), and (f) Knight Butterfly (Labadea martha).

(Photo credits: Sharif A. Mukul) 

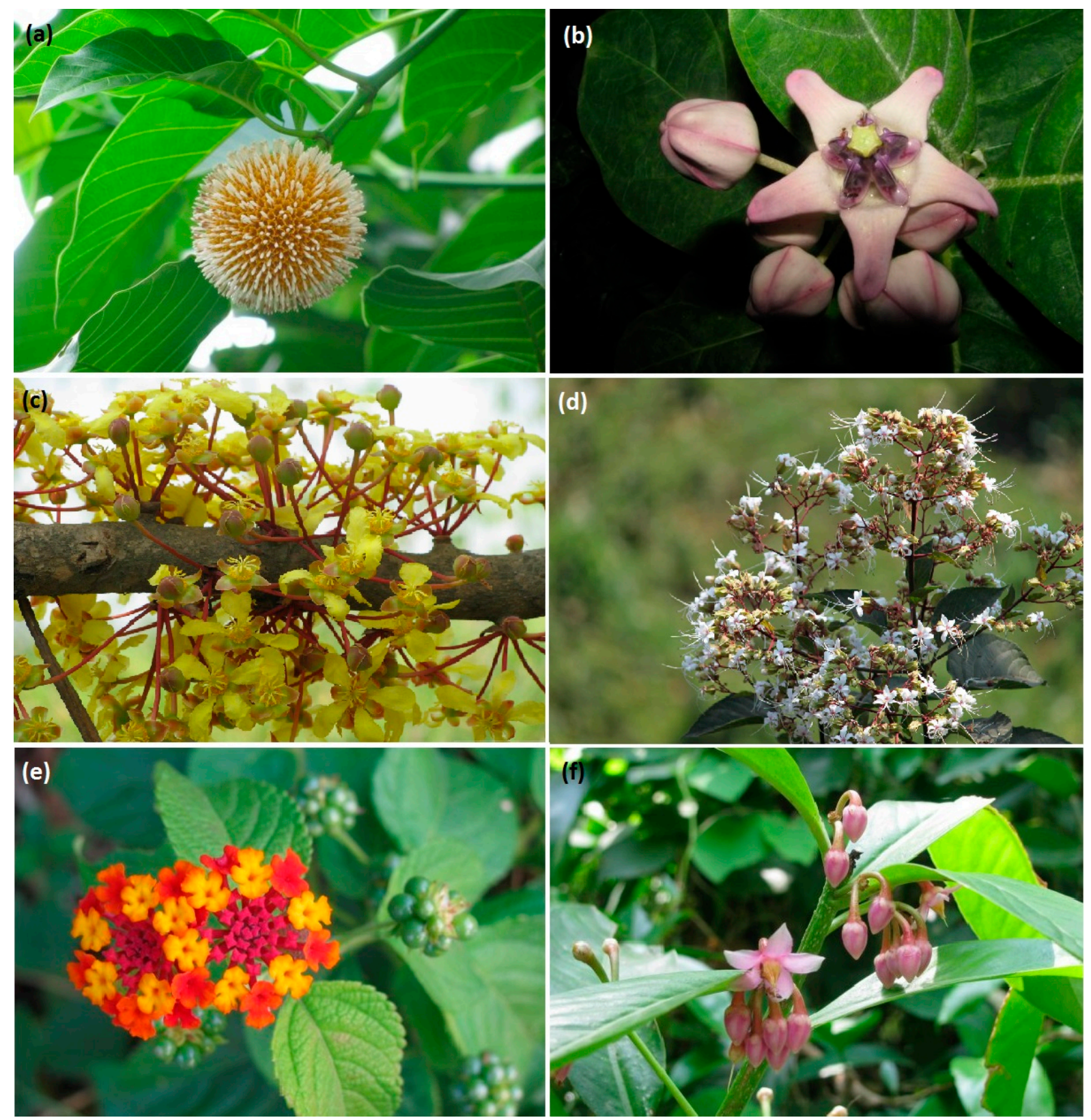

PLATE 3: Plant diversity in Bangladesh: from top left - (a) Kadam (Anthocephalus chinensis), (b) Akanda (Calotropis gigantean), (c) Ban chalta (Dillenia pentagyna), (d) Bhat (Clerodendrum fragrans), (e) Lantana (Lantana camara), and (f) Bon jam (Ardisia colrata). (Photo credits: Sharif A. Mukul) 

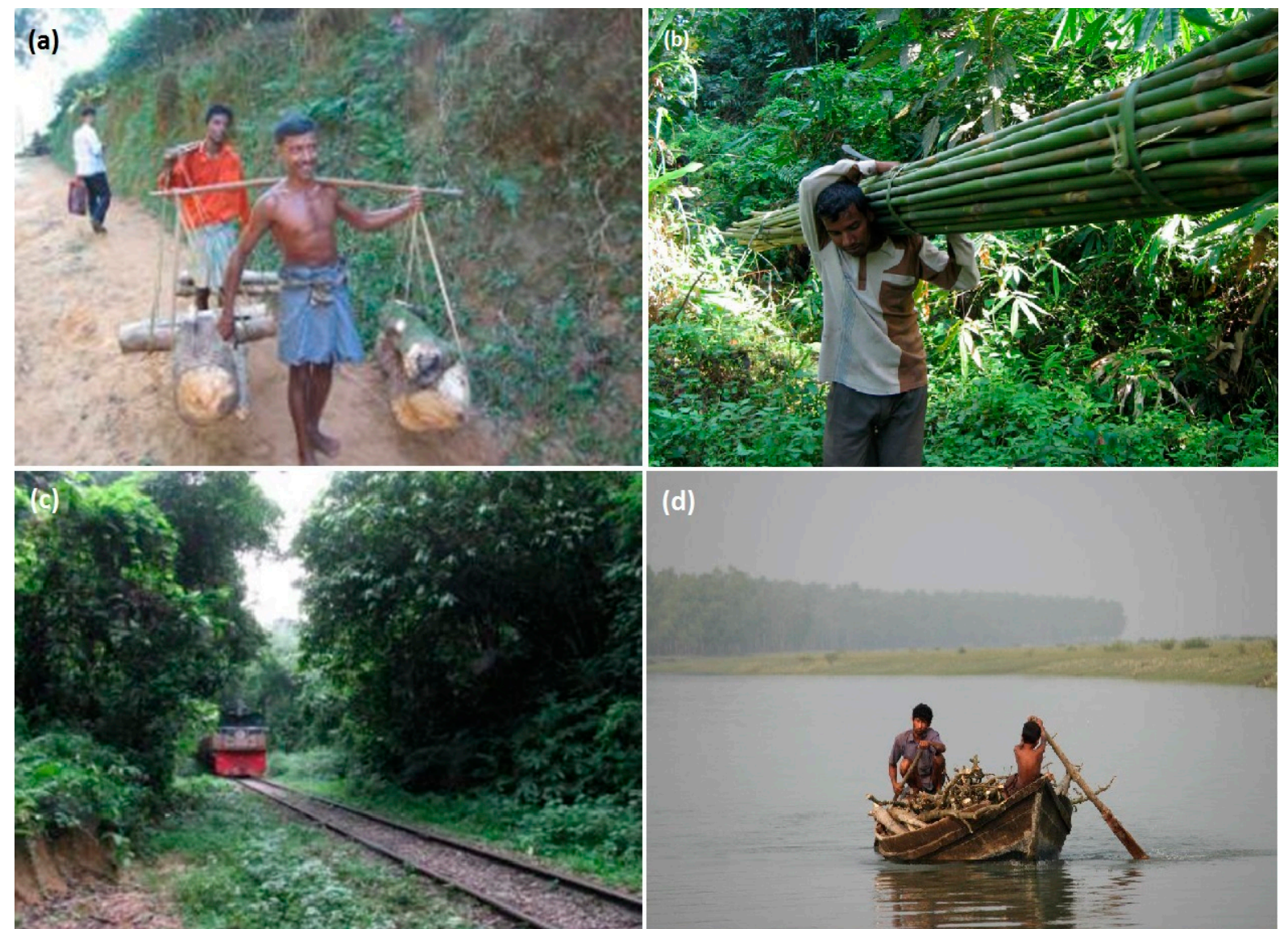

(d)
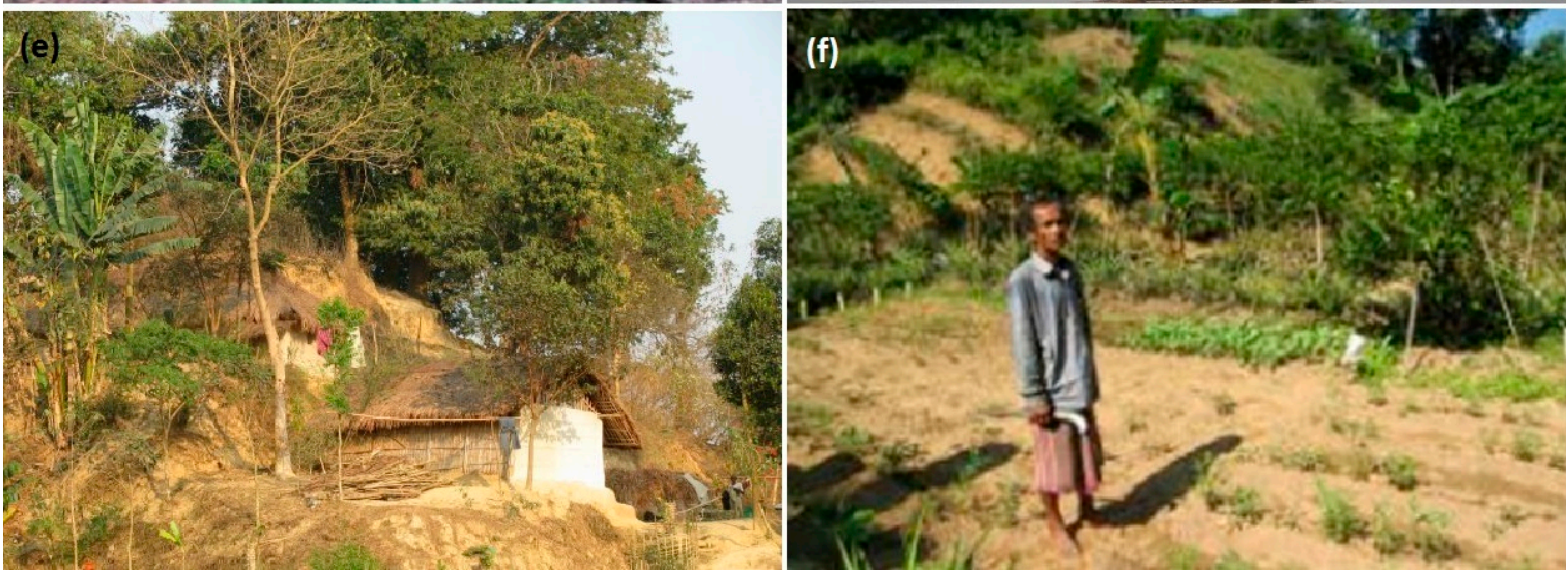

PLATE 4: Major causes of forest loss and disturbances in Bangladesh: (a) illegal logging in forests in Sylhet, (b) unsustainable non-timber forest products collection, (c) transportation through natural forests, (d) fuelwood collection, (e) encroachment of forest lands, and (f) agricultural expansion in forest lands.

(Photo credits: Sharif A. Mukul)

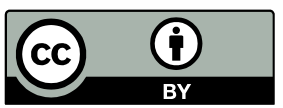

(C) 2017 by the authors; licensee Preprints, Basel, Switzerland. This article is an open access article distributed under the terms and conditions of the Creative Commons by Attribution (CC-BY) license (http://creativecommons.org/licenses/by/4.0/). 